\title{
Fetal Macrosomia in Diabetic Multiparous Animals
}

\author{
Y. S. Kim, Y. Yoon, I. Jatoi, and Y. Kim \\ Department of Pharmacology, St. Louis University School of Medicine, St. Louis, Missouri, USA
}

Summary. Mild diabetes (blood glucose ranging from 130 to $200 \mathrm{mg} / 100 \mathrm{ml}$ ) was induced in female rats by streptozotocin administration prior to mating. $\mathrm{Fe}-$ tuses obtained from these diabetic mothers on 20.5, 19.5 and 18.5 days of gestation were compared with corresponding fetuses from control mothers. Macrosomia was defined as a fetus whose body weight exceeded the mean $+2.5 \mathrm{SD}$ of fetal weight obtained from the control fetal population. Similarly, the rate of substrate influx was considered abnormally high when an individual value (cpm/g tissue of radioactive tracer) exceeded mean $+2.5 \mathrm{SD}$ of control value. The frequencies of macrosomia in control groups and in diabetic groups were 1/98 and 15/110 respectively, on 20.5 day of gestation, 1/155 and 14/ 148 on 19.5 day, and $0 / 99$ and $0 / 98$ on 18.5 day. The rates of influx of thymidine, leucine, and alphaaminoisobutyric acid from maternal side to the macrosomic fetuses were increased as much as 20 times the corresponding rates in control fetuses. Despite the lack of macrosomia as defined here in the fetal population on 18.5 day of gestation, a significantly larger proportion of litters from diabetic mothers ( 5 litters $/ 5$ litters) contained one or more fetuses showing abnormally high rate of thymidine influx than the litters from control mothers $(0$ litter $/ 5$ litters). These results suggest that only a selected few fetuses in a litter from a diabetic mother become macrosomic and a marked stimulation in the rate of metabolite influx into fetuses precedes the manifestation of macrosomia.

Key words: Streptozotocin diabetes in rat, fetal macrosomia, rate of substrate influx, leucine influx, thymidine influx, AIB influx
In order to elucidate the mechanism of pathogenesis of macrosomia in diabetic pregnancy, we have previously examined the syntheses of proteins and DNA in the fetuses and neonates from normal and diabetic rats [1]. In the course of these studies, evidence was obtained suggesting that in multiparous animals the intrauterine milieu does not influence uniformly all fetuses in the same litter. Furthermore, one of the most pronounced changes associated with fetal macrosomia appeared to be the rate of influx of metabolites from the maternal side to the fetus. We have, therefore, examined the frequency of macrosomia in pregnancies of control and diabetic rats, and the rates of transport of radioactive tracers from the maternal side to the fetuses.

\section{Materials and Methods}

Sprague-Dawley rats were obtained from ARS Co. (Madison, WI). Animals were given Purina Rat Chow (Purina Co., St. Louis, $\mathrm{MO})$ and water ad libitum. All biochemicals including streptozotocin (Lot No. S-0130) were obtained from Sigma Chemicals Co. (St. Louis, MO). (Methyl- $\left.{ }^{3} \mathrm{H}\right)$-thymidine $(70 \mathrm{Ci} / \mathrm{mmol}), \mathrm{L}-(4,5-$ $\left.{ }^{3} \mathrm{H}\right)$-leucine $(50 \mathrm{Ci} / \mathrm{mmol})$, and alpha-(methyl- $\left.{ }^{3} \mathrm{H}\right)$-aminoisobutyric acid $\left({ }^{3} \mathrm{H}\right.$-AIB, $\left.20 \mathrm{Ci} / \mathrm{mmol}\right)$ were obtained from New England Nuclear Corp. (Boston, MA). All other chemicals were obtained from Fisher Scientific Co. (St. Louis, MO).

\section{Selection of Mildly Diabetic Animals}

Female rats were given $32 \mathrm{mg} / \mathrm{kg}$ of streptozotocin IP according to the method described previously [1]. On the 10th day thereafter blood was obtained from tail veins of each animal at $0800 \mathrm{~h}$ and the blood glucose concentration was estimated by the method of Jarrett et al. [2]. The procedure was repeated for the three consecutive mornings, and those animals whose average glucose value was between 130 and $200 \mathrm{mg} / 100 \mathrm{ml}$ were selected as mildly diabetic animals, and were subsequently mated.

In our previous studies animals excreting $0.01-0.99 \mathrm{~g} /$ day of glucose were termed as mildly diabetic animals [1]. Subsequent 
studies showed that the blood glucose level of these animals never exceeded $300 \mathrm{mg} / 100 \mathrm{ml}$ by the method of Jarrett et al. [2].

\section{Mating and Collection of Fetus}

The methods of mating and collection of fetuses have been described previously [1]. Briefly, a group of 10 female rats (both control and diabetic) weighing $200-250 \mathrm{~g}$ was housed in one cage, and one male rat was placed in the cage from $1700 \mathrm{~h}$ to $0800 \mathrm{~h}$. The animals were weighed and inspected every morning between $0800 \mathrm{~h}$ and $0900 \mathrm{~h}$. The presence of sperm on vaginal smears indicated mating, and the gestation period at this time was considered 0.5 day. One male rat was used for mating until sufficient numbers of matching litters of fetuses were obtained from both normal and diabetic mothers for a set of experiments.

Between $0900 \mathrm{~h}$ and $1000 \mathrm{~h}$ on the 20.5 day of gestation, each pregnant mother was given either $20 \mu \mathrm{Ci} / 100 \mathrm{~g}$ body weight of ${ }^{3} \mathrm{H}-$ thymidine or $20 \mu \mathrm{Ci} / 100 \mathrm{~g}$ of ${ }^{3} \mathrm{H}$-leucine IP. Exactly $120 \mathrm{~min}$ thereafter the mother rat was sacrificed by decapitation. Each fetus was isolated, yolk sack and umbilical cord removed, and then the fetus was rinsed in a cold buffer solution containing the following in mmol/l: Tris- $\mathrm{HCl}, 37.0(\mathrm{pH} 7.3) ; \mathrm{KCl}, 50.0 ; \mathrm{MgCl}_{2}, 3.3$; EDTA, 0.5; 2-mercaptoethanol, 6.0. After blotting to remove excessive buffer solution, the fetuses were weighed individually and the number of fetuses in a litter was counted.

A total of 9 litters containing 98 fetuses was collected from control mothers on the 20.5 day of gestation, and the mean fetal weight and standard deviation of the mean (SD) were determined. Any fetus (either from control or diabetic mother) whose weight exceeded this mean value by 2.5 times the SD (mean $+2.5 \mathrm{SD}$ ) was defined as macrosomic fetus.

Fetuses were also collected from normal and diabetic mothers on 19.5 and 18.5 days of gestation. Each of the pregnant animals received $20 \mu \mathrm{Ci} / 100 \mathrm{~g}$ body weight of ${ }^{3} \mathrm{H}$-thymidine, $20 \mu \mathrm{Ci} / 100 \mathrm{~g}$ of ${ }^{3} \mathrm{H}$-leucine or $10 \mu \mathrm{Ci} / 100 \mathrm{~g}$ of ${ }^{3} \mathrm{H}$-AIB IP $2 \mathrm{~h}$ before the animal was sacrificed. Fetuses were collected in a similar manner as that described for the animals on 20.5 day of gestation. The number of macrosomic fetuses for each litter and for each set of experiments was determined in order to evaluate the frequencies of macrosomia.

\section{Measurement of Radioactivity}

Fetuses were killed and homogenized individually in the buffer solution in a Polytron homogenizer for $0.5 \mathrm{~min}$, and the final concentration was adjusted to $1 \mathrm{~g}$ of fetus per $10 \mathrm{ml}$ of total homogenate. Aliquots of the total homogenate were solubilized in equal volumes of $0.05 \mathrm{~mol} / 1 \mathrm{NaOH}$ solution and $0.2 \mathrm{ml}$ of the solubilized sample was placed in a scintillation counting vial, and the radioactivity was measured in a Beckman CPM 100 scintillation counter. The counting method has been described elsewhere in detail $[3,4]$. From these results the amount of radioactivities in the fetus (cpm of ${ }^{3} \mathrm{H}$-thymidine, ${ }^{3} \mathrm{H}$-leucine or ${ }^{3} \mathrm{H}$-AIB per $\mathrm{g}$ of fetus) was determined.

\section{Statistical Methods}

Statistical analyses were performed according to the methods described by Hill [5] and Conover [6]. Data were expressed in mean $\pm \mathrm{SD}$ whenever it is appropriate. A fetus was considered macrosomic when its body weight was greater than mean body weight of fetuses from control group of mothers by 2.5 times SD. Similarly, the amount of radioactivity (e. g. cpm of ${ }^{3} \mathrm{H}$-thymidine/g of fetus) in an individual fetus was considered abnormally high if the value exceeded the control mean $+2.5 \mathrm{SD}$ value. The signifi- cance of difference between the frequency of macrosomia in the control fetal population and the corresponding frequency in the fetal population from diabetic mothers was assessed by Chi-square test. The rate of thymidine influx was evaluated by two methods: The means of litter average values for control and diabetic groups were evaluated by Wilcoxon-Mann-Whitney test. The frequencies of litter containing one or more fetuses showing abnormally high rate of influx were evaluated by Fisher's exact test.

\section{Results}

Table 1 summarizes data describing all the fetuses. The frequency of macrosomia was significantly greater in pregnancies of diabetic animals on both 20.5 and 19.5 days of gestation on the basis of Chi-square test. The macrosomic fetuses were distributed evenly among the litters from diabetic mothers, and none of the litters contained more than 2 macrosomic fetuses. In any event, none of the fetuses obtained on the 18.5 day of gestation was macrosomic by the criterion employed here.

Table 2 compares the amounts of radioactive tracers in control and macrosomic fetuses. The amount of radioactivity in the macrosomic fetuses (cpm/g fetus) was more than 20 times greater than that in control fetuses for all tracers used. On the other hand, the radioactivity values for control fetuses (fetuses from control mothers) were similar to the radioactivity values for normal-weight litter mates of the macrosomic fetuses (from diabetic mothers).

Table 3 shows the rate of thymidine influx into fetuses from control and diabetic mothers on the 18.5 day. Despite the lack of macrosomia in diabetic pregnancies on the 18.5 day (Table 1 ), the frequency of an abnormally high rate of thymidine influx was significantly greater in the fetal population from diabetic mothers than in the control fetal population. The mean of litter average in the table indicated that the average radioactivity value from fetuses in each of the diabetic litters was significantly greater than the corresponding value from the control litters.

\section{Discussion}

Recent work has shown that in animal model systems fetal and neonatal macrosomia is manifested only under mildly diabetic conditions of mothers $[1,7,8]$. In these studies the macrosomia was defined in terms of mean fetal weight of litters or of all fetuses obtained from diabetic mothers. The mean macrosomic body weight thus obtained differs from normal weight by up to $20 \%$, which contrasts to that of human diabetic pregnancy in which a $100 \%$ increase 
Table 1. Frequency of macrosomia in control and diabetic pregnancies

\begin{tabular}{llll}
\hline Fetal status & $\begin{array}{l}\text { Number of } \\
\text { fetuses }\end{array}$ & $\begin{array}{l}\text { Mean fetal } \\
\text { weight } \\
(\mathrm{g})\end{array}$ & $\begin{array}{l}\text { Number of } \\
\text { macrosomic } \\
\text { fetuses }\end{array}$ \\
& & $\begin{array}{l}>\text { mean }+ \\
2.5 \text { SD con- } \\
\text { trol) }\end{array}$ \\
& &
\end{tabular}

20.5day old fetus from:

Control mother (9) 98

Diabetic mother (11) 110

$\begin{array}{lc}4.11 \pm 0.34 & 1 \\ 4.68 \pm 0.50 & 15^{\mathrm{a}} \\ & \\ 2.74 \pm 0.28 & 1 \\ 2.89 \pm 0.30 & 14^{\mathrm{a}} \\ & \\ 1.69 \pm 0.13 & 0 \\ 1.66 \pm 0.16 & 0\end{array}$

19.5 day old fetus from:

Control mother (15) 155

Diabetic mother (15) 148

18.5 day old fetus from:

Control mother (9) 99

Diabetic mother (9) 98

Number of litters in parenthesis

a $\mathrm{p}<0.05$ for $\varkappa^{2}$ test

in the fetal weight is sometimes observed. In the present study, those fetuses which weighed more than the mean $+2.5 \mathrm{SD}$ (of control fetuses) were classified into a macrosomic group, but the individual weights of macrosomic fetuses often reached twice the control fetal weight.

In multiparous animals whether or not the intrauterine milieu influences equally all fetuses in the litter has been a matter of conjecture. The results presented here show that maternal diabetes affects transport mechanisms of a selected few fetuses in a litter. Furthermore, the increase in metabolite influx is consistent with manifestation of macrosomia in diabetic pregnancy.

Even though ${ }^{3} \mathrm{H}$-AIB data unequivocally show the increase in the influx rate [9], interpretation of the ${ }^{3} \mathrm{H}$-leucine data requires knowledge of specific radioactivity in the maternal pool. The plasma levels of leucine on both maternal and fetal sides tend to increase in maternal diabetes $[10,11]$, and the specific radioactivity of leucine in the pools of diabetic mother (after IP injection of ${ }^{3} \mathrm{H}$-leucine) should be lower than that in normal mother. Therefore, the actual increase in the rate of influx in macrosomic fetuses should be greater than that indicated by the radioactivity values. In any event, the difference between the radioactivity value $(\mathrm{cpm} / \mathrm{g}$ ) of the macrosomic fetus and the value of its normal litter mates was similar to the difference between the radioactivity value of the macrosomic fetus and the corresponding value of the fetuses from control mother.

The results presented in Table 3 suggest that changes in the rate of influx precede the manifestation of fetal macrosomia in diabetic pregnancy.
Table 2. Influx of radioactive tracers into control fetus, normal litter mate of macrosomic fetus, and macrosomic fetus

\begin{tabular}{|c|c|c|c|}
\hline \multirow[t]{2}{*}{ Fetal status } & \multicolumn{3}{|c|}{$\left(\mathrm{cpm} / \mathrm{g}\right.$ of fetus) $\times 10^{-3}$} \\
\hline & ${ }^{3} \mathrm{H}$-Thymidine & ${ }^{3} \mathrm{H}$-Leucine & ${ }^{3} \mathbf{H}$-AIB \\
\hline \multicolumn{4}{|l|}{20.5 day old } \\
\hline $\begin{array}{l}\text { Control fetus } \\
\text { (from control } \\
\text { mother) }\end{array}$ & $\begin{array}{l}43.6 \pm 3.3 \\
(44)\end{array}$ & $\begin{array}{l}50.1 \\
(54)\end{array}$ & \\
\hline $\begin{array}{l}\text { Normal litter mate } \\
\text { (from diabetic } \\
\text { mother) }\end{array}$ & $\begin{array}{l}49.7 \pm 4.8 \\
(48)\end{array}$ & $\begin{array}{l}52.1 \\
(47)\end{array}$ & \\
\hline $\begin{array}{l}\text { Macrosomic fetus } \\
\text { (from diabetic } \\
\text { mother) }\end{array}$ & $\begin{array}{l}1,323 \pm 188 \\
(7)\end{array}$ & $\begin{array}{l}1,157 \pm 274 \\
(8)\end{array}$ & \\
\hline $\begin{array}{l}19.5 \text { day old } \\
\text { Control fetus } \\
\text { (from control } \\
\text { mother) }\end{array}$ & $\begin{array}{l}45.1 \pm 2.2 \\
(56)\end{array}$ & $\begin{array}{l}49.5 \pm 10.0 \\
(51)\end{array}$ & $\begin{array}{l}46.0 \pm 6.2 \\
(48)\end{array}$ \\
\hline $\begin{array}{l}\text { Normal litter mate } \\
\text { (from diabetic } \\
\text { mother) }\end{array}$ & $\begin{array}{l}41.8 \pm 3.5 \\
(48)\end{array}$ & $\begin{array}{l}52.2 \pm 9.5 \\
(40)\end{array}$ & $\begin{array}{l}42.1 \\
(46)\end{array} \pm 6.1$ \\
\hline $\begin{array}{l}\text { Macrosomic fetus } \\
\text { (from diabetic } \\
\text { mother) }\end{array}$ & $\begin{array}{l}1,471 \pm 778 \\
(4)\end{array}$ & $\begin{array}{l}1,361 \pm 213 \\
(6)\end{array}$ & $\begin{array}{l}1,653 \pm 266 \\
(4)\end{array}$ \\
\hline
\end{tabular}

Number of animals in parenthesis

Table 3. Rate of radioactive thymidine influx into 18.5 day old fetus

\begin{tabular}{lll}
\hline $\begin{array}{l}\text { Maternal } \\
\text { status }\end{array}$ & $\begin{array}{l}\text { Mean of litter average } \\
{ }^{3} \mathrm{H} \text {-thymidine } \\
\text { (cpm/g fetus) } \times 10^{-3}\end{array}$ & $\begin{array}{l}\text { Number of litters } \\
\text { containing one or } \\
\text { more } \\
\text { fetuses showing } \\
\text { abnormal } \\
\text { rate of influx }\end{array}$ \\
\hline Control & $\begin{array}{l}44.5 \\
(5)\end{array}$ & 0 \\
Diabetic & $53.0^{\mathrm{a}}$ & $5^{\mathrm{b}}$ \\
& $(5)$ & \\
\hline
\end{tabular}

Number of litters in parenthesis

${ }^{\mathrm{a}} \mathrm{p}<0.05$ for Wilcoxon-Mann-Whitney test

b $\mathrm{p}<0.05$ for Fisher's exact test

Whether or not the change in transport mechanism is the rate limiting factor for the expression of macrosomia has yet to be determined. The increase in the rate of influx precedes both the increase in the fetal tissue level of DNA polymerase activities and the increase in fetal pancreatic insulin in diabetic pregnancies of rats $[1,7]$.

The findings reported in this paper provide a rationale for comparing litter mates in investigating the effect of maternal diabetes on the fetus, a model system which will be a valuable tool for elucidating mechanisms of macrosomia and other consequences 
of maternal diabetes. Perhaps more significantly, we have described a fetal parameter which undergoes a very marked change in association with fetal macrosomia in diabetic pregnancy - the rate of metabolite influx into fetus from the maternal side.

Acknowledgement. This work was supported by a research grant, HD 11614, from the NICHD, USPHS.

\section{References}

1. Kim YS, Jatoi I, Kim Y (1980) Neonatal macrosomia in maternal diabetes. Diabetologia 18: 407-411

2. Jarrett RJ, Keen H, Hardwick C (1970) Instant blood sugar measurement using Dextrostix and a reflectance meter. Diabetes 19: 724-726

3. Kim YS (1968) The sequential increase in the rates of synthesis of enzymes in rat liver after glucocorticoid administration. Mol Pharmacol 4: 168-172

4. Kim YS, Kim Y (1975) Glucocorticoid inhibition of protein synthesis in vivo and in vitro. J Biol Chem 250: 2293-2298

5. Hill AB (1961) Principles of medical statistics. Oxford University Press, New York, p 133-179
6. Conover WJ (1971) Practical nonparametric statistics. John Wiley and Sons, New York, p 162-229

7. Kervran A, Guillaume M, Jost A (1978) The endocrine pancreas of fetus from diabetic pregnant rat. Diabetologia 15: 387-393

8. Aerts L, Van Assche FA (1977) Rat foetal endocrine pancreas in experimental diabetes. J Endocrinol 73: 339-346

9. Chambers JW, Georg RM, Bass AD (1965) Effect of hydrocortisone and insulin on uptake of alpha-aminobutyric acid by isolated perfused rat liver. Mol Pharmacol 1: 66-76

10. Garlsten A, Hallgren B, Jagenburg R, Svanborg A, Werko L (1966) Amino acids and free fatty acids in plasma in diabetes. Acta Med Scand 179: 361-370

11. Chez RA (1978) Placental transport of hexoses and amino acids. In: Warshaw JB, Bloom RS, Sinclair JC (eds) Mead Johnson Symposium on Perinatal and Developmental Medicine No 13. Mead Johnson, Evansville, p 33-39

Received: June 24, 1980

and in revised form: October 6, 1980

Dr. Yee S. Kim, Professor

Department of Pharmacology

St. Louis University School of Medicine

1402 South Grand Boulevard

St. Louis, MO 63104

USA 